\title{
Physical condition of felsic magma constrained by experimentally-determined phase relations
}

\author{
Toshimori SeKine ${ }^{1}$ and Shigeo Aramaki ${ }^{2 *}$ \\ National Institute for Research in Inorganic Materials, 1-1 Namiki, Tsukuba 305, and \\ Earthquake Research Institute, University of Tokyo, Bunkyo-ku, Tokyo 113, Japan
}

(Received February 12, 1992; Accepted September 25, 1992)

\begin{abstract}
Near-liquidus relations in one-atomsphere dry and water saturated high pressure conditions were experimentally determined on a pumice erupted from Usu volcano, Hokkaido, on August 14, 1977, at temperatures of $890^{\circ} \mathrm{C}$ to $1220^{\circ} \mathrm{C}$, up to $1400 \mathrm{bar}$, and at a fixed oxygen fugacity $\left(\mathrm{fo}_{2}\right)$ close to the $\mathrm{Ni}-\mathrm{NiO}$ buffer. Plagioclase was the liquidus phase and accompanied with the subsequent phase of orthopyroxene up to 1400 bar. The temperature difference between the plagioclase and orthopyroxene liquidi decreases with increasing water pressure, and an extraporation showed a crossing at about $900^{\circ} \mathrm{C}$ and 1500 bar. This temperature and water pressure may approximate the physical condition of the Usu magma containing both plagioclase and orthopyroxene as a small amount of phenocrysts shortly prior to eruption if the magma was saturated with $\mathrm{H}_{2} \mathrm{O}$.

Summarizing the experimentally-determined, $\mathrm{H}_{2} \mathrm{O}$-saturated coprecipitation pressures and temperatures for the liquidus minerals from felsic magmas, so far reported in literature, a clear relationship is empirically derived for magmatic water pressure, temperature and the chemical composition of magmas. Using a compositional parameter such as the normative ratio of plagioclase to the sum of plagioclase plus pyroxene, the maximum water pressure and minimum temperature of magma immediately prior to eruption can be estimated graphically. This information may be useful to infer the physical conditions for historical activities of volcanoes vased on the mineralogical and petrochemical investigations.
\end{abstract}

\section{INTRODUCTION}

Explosive volcanic eruptions and the processes of ascending magmas from magma chamber through conduit are currently being understood from several views such as field observations during and after eruptions, petrological methods, and experimentally determined phase relations. Volcanic eruptions related to felsic magmas such as andesite, dacite, and rhyolite are characterized by sudden gas release from the ascending magmas. The calcalkaline rock type has distinctive tectonic settings, associated primarily with convergent plate boundaries, although some are related to in- terplate basaltic volcanism on continental and oceanic rifts and oceanic islands(Gill, 1981).

The stability of crystalline phases in magma is closely related to the physical conditions of temperature and gas pressure. These are the most important parameters influencing the mineral stabilities. Reliable data on phase relations have been accumulated for the systems, natural felsic rock-gas component and model rock-gas component (e.g. Aramaki, 1971; Eggler, 1972 and 1974; Eggler and Burnham, 1973; Maksimov et al., 1978; Sekine et al., 1979; Merzbacher and Eggler, 1984; Rutherford and Devine, 1988). especially in which the main gas component is water. $\mathrm{CO}_{2}$ in felsic magmas plays

${ }^{*}$ Present Address: Department of Geology and Mineralogy, Hokkaido University, Sapporo, Hokkaido 060, JAPAN. 
less important role in the liquidus relations, especially over the relatively low pressure range of 1 to 500 bar (Eggler, 1972).

First part of the present paper describes experimental results on near-liquidus phase relations under $\mathrm{H}_{2} \mathrm{O}$-saturated and $\mathrm{fo}_{2}$-controlled conditions of the 1977 Usu pumice, erupted on August 14, 1977 (Katsui et al., 1978). This pumice contains less than a few percent of phenocrystic plagioclase, orthopyroxene and titanomagnetite. The magmatic conditions just prior to or at the time of eruption may be deduced from the experimental results, assuming that the phenocryst assemblages were precipitating in equilibrium with the magma shortly prior to eruption. The stability of titanomagnetite has been shown to be greatly influenced by magmatic $\mathrm{fo}_{2}$ (Sekine et al., 1979).

If a magma with a particular composition is saturated with water in the magma chamber, the deduced magmatic condition of temperature and water pressure for various magmas should also be a function of the chemical composition, although the deduced conditions indicate only the maximum water pressure and the minimum temperature in the case of $\mathrm{H}_{2} \mathrm{O}$-undersaturated magmas.

By summarizing the physical conditions deduced from experimentally-determined phase relations for several magmas, we have found a clear relationship between the chemical composition of magma and the deduced magmatic water pressure and temperature. The chemical composition of the magma is represented by the normative ratio, plagioclase (albite + anorthite) to the sum of plagioclase and pyroxene (wollastonite + enstatite + ferrosilite) in andesitic melts (Sekine, 1986). Using these empirical relations, one may be able to calculate magmatic conditions for historic eruptions with felsic rocks, and also to predict quantitatively a possible intensity of explosion and the risk for each volcano as constrained by the composition of magma. The temperature and water pressure thus calculated correspond to the minimum and maximum values, respectively, as they assume water-saturation.

\section{EXPERIMENTAL}

The starting material used in the present study is a pumice erupted on August 14, 1977 (Big IV pumice of Katsui et al., 1978). Under the microscope, it consists of about $98 \mathrm{vol} \%$ groundmass glass and the remainder of phenocrystic plagioclase, hypersthene and titanomagnetite. The chemical compositions of the plagioclase, hypersthene and titanomagnetite were determined with an electron probe microanalyzer, as listed in Table 1. Compositions of the hypersthene and titanomagnetite did not change significantly throughout the four major eruptions in 1977. Those of plagioclase ranged from 56.5 to $63.4 \mathrm{~mol} \% \mathrm{An}$ in the Big I pumice, through 51.5 to $56.9 \mathrm{~mol} \% \mathrm{An}$ in the Big II and 56.0 to $65.0 \mathrm{~mol} \% \mathrm{An}$ in the Big III (Katsui et al., 1978), to 58 to $70 \mathrm{~mol} \% \mathrm{An}$ in the Big IV (Table 1). The pumices of Big I, II, and III stages showed a gradual decrease in vesicularity with time, but the Big IV pumice resumed higher vesicularity almost as high as the Big I pumice (Katsui et al., 1978). Assuming ballistic trajectory for relatively large and dense blocks, the initial velocity of ejecta was estimated to be $230 \pm 10 \mathrm{~m} / \mathrm{sec}$ (Katsui et al., 1978). Oshima (1977) estimated the temperature of the magma to be $900 \pm 50^{\circ} \mathrm{C}$, using an empirical relation of $\mathrm{Mg}$ and $\mathrm{Mn}$ contents in the phenocrystic

Table 1. Microprobe analyses of minerals in the Big IV pumice of the 1977 eruption from Usu volcano

\begin{tabular}{|c|c|c|c|c|c|c|c|}
\hline \multirow[b]{2}{*}{$\mathrm{SiO}_{2}$} & \multicolumn{2}{|c|}{ plagioclase } & \multicolumn{2}{|c|}{ hypersthene } & \multicolumn{3}{|c|}{ titanomagnetite } \\
\hline & 50.6 & 53.3 & 51.0 & 51.5 & 0.0 & & 0.11 \\
\hline $\mathrm{TiO}_{2}$ & - & - & 0.19 & 0.26 & 10.8 & & 11.0 \\
\hline $\mathrm{Al}_{2} \mathrm{O}_{3}$ & 31.2 & 28.6 & 0.98 & 1.44 & 2.6 & & 2.53 \\
\hline $\mathrm{FeO}^{*}$ & 0.52 & 0.43 & 25.3 & 22.0 & 78.9 & & 78.4 \\
\hline $\mathrm{MnO}$ & 0.00 & 0.00 & 1.58 & 1.16 & 0.6 & & 0.79 \\
\hline $\mathrm{MgO}$ & 0.03 & 0.05 & 18.4 & 21.1 & - & & - \\
\hline $\mathrm{CaO}$ & 14.0 & 12.4 & 1.32 & 1.60 & 一 & & - \\
\hline $\mathrm{Na}_{2} \mathrm{O}$ & 3.39 & 4.88 & 0.00 & 0.02 & 一 & & - \\
\hline $\mathrm{K}_{2} \mathrm{O}$ & 0.04 & 0.05 & - & - & - & & - \\
\hline total & 99.78 & 99.71 & 98.77 & 99.08 & 94.6 & & 94.34 \\
\hline \multicolumn{2}{|c|}{$\mathrm{mol} \%$} & \multicolumn{2}{|c|}{ atomic\% } & \multicolumn{4}{|c|}{ recalculated } \\
\hline Or & 0.3 & $0.3 \mathrm{Ca}$ & 2.8 & $3.3 \mathrm{I}$ & $\mathrm{Fe}_{2} \mathrm{O}_{3}$ & 45.5 & 545.0 \\
\hline $\mathrm{Ab}$ & 30.34 & $41.4 \mathrm{Mg}$ & 53.5 & $59.9 \mathrm{I}$ & $\mathrm{FeO}$ & 38.3 & 338.2 \\
\hline An & 69.45 & $58.3 \mathrm{Fe}$ & 43.7 & $36.9 \mathrm{t}$ & otal & 99.5 & 599.14 \\
\hline
\end{tabular}

$\mathrm{FeO}^{*}=$ total $\mathrm{Fe}$ as $\mathrm{FeO}$. 
titanomagnetite.

The sample was collected from the middle layer of the Big IV pumice fall deposit and ground below $10 \mu \mathrm{m}$ in an agate mortor with acetone. The chemical composition is given in Table 2 (Katsui et al., 1978), together with the norm.

Melting and crystallization experiments were carried out under controlled oxygen fugacity using $\mathrm{CO}_{2}-\mathrm{H}_{2}$ gas mixture at $1 \mathrm{~atm}$ and under water-saturated conditions using $\mathrm{Ar}-\mathrm{H}_{2}$ gas mixture up to $1400 \mathrm{bar}$ in an internally-heated pressure vessel. The experimental details are the same as described by Sekine et al. (1977, 1979). The $\mathrm{fo}_{2}$ was kept close to that of the Ni-NiO buffer throughout runs. Although silicate liquidi are substantially little affected by $\mathrm{fo}_{2}$, the stability of magnetite is extended to higher temperatures at higher $\mathrm{fo}_{2}$ (Sekine et al., 1979).

\section{RESUlts}

Experimental results on the Usu pumice under $\mathrm{H}_{2} \mathrm{O}$-saturated conditions are summarized in Table 3 and Fig. 1. Equilibrium was checked using two sets of starting materials, i.e. (1) finely-ground raw rock powder containing fragments of phenocrysts and (2) quenched glass made by heating the rock powder above the liquidus temperature.

At $1 \mathrm{~atm}$, the plagioclase liquidus tempera-

Table 2. Chemical composition of the Big IV pumice of Usu volcano (Katsui et al., 1978) used in the present study

\begin{tabular}{lrlr}
\hline $\mathrm{SiO}_{2}$ & 68.57 & $\mathrm{CIPW}$ norm & \\
$\mathrm{TiO}_{2}$ & 0.50 & $\mathrm{Q}$ & 28.00 \\
$\mathrm{Al}_{2} \mathrm{O}_{3}$ & 15.58 & or & 6.68 \\
$\mathrm{Fe}_{2} \mathrm{O}_{3}$ & 1.45 & $\mathrm{ab}$ & 37.75 \\
$\mathrm{FeO}$ & 2.49 & an & 18.39 \\
$\mathrm{MnO}$ & 0.16 & $\mathrm{C}$ & 0.28 \\
$\mathrm{MgO}$ & 0.79 & en & 1.97 \\
$\mathrm{CaO}$ & 4.06 & fs & 2.55 \\
$\mathrm{Na}_{2} \mathrm{O}$ & 4.46 & mt & 2.11 \\
$\mathrm{~K}_{2} \mathrm{O}$ & 1.13 & il & 0.96 \\
$\mathrm{P}_{2} \mathrm{O}$ & 0.27 & ap & 0.64 \\
$\mathrm{H}_{2} \mathrm{O}(+)$ & 0.24 & & \\
$\mathrm{H}_{2} \mathrm{O}(-)$ & 0.12 & & \\
$\mathrm{Total}$ & 99.82 & & \\
\hline
\end{tabular}

Table 3. Experimental conditions of the Usu pumice erupted on August 14, 1977. The oxygen fugacity was kept to be close to the Ni-NiO buffer. In high pressure runs, samples were saturated with $\mathrm{H}_{2} \mathrm{O}$.

\begin{tabular}{|c|c|c|c|}
\hline $\operatorname{Temp}\left({ }^{\circ} \mathrm{C}\right)$ & $\begin{array}{l}\text { Press } \\
\text { (bar) }\end{array}$ & $\begin{array}{c}\text { Duration } \\
\text { (hrs) }\end{array}$ & Phases present \\
\hline $1215 \pm 2$ & 1 & 2 & $\mathrm{gl}+\mathrm{pl}(\mathrm{tr})$ \\
\hline $1214 \pm 2$ & 1 & 8 & $\mathrm{gl}+\mathrm{pl}(\mathrm{tr})$ \\
\hline $1206 \pm 2$ & 1 & 48 & $\mathrm{gl}+\mathrm{pl}$ \\
\hline $1197 \pm 2$ & 1 & 53 & [gl] \\
\hline $1185 \pm 2$ & 1 & 133 & $\begin{array}{l}\mathrm{gl}+\mathrm{pl}(\mathrm{tr}) \\
{[\mathrm{gl}+\mathrm{pl}]}\end{array}$ \\
\hline $1180 \pm 1$ & 1 & 94 & $\begin{array}{l}\mathrm{gl}+\mathrm{pl} \\
{[\mathrm{gl}+\mathrm{pl}]}\end{array}$ \\
\hline $1155 \pm 2$ & 1 & 161 & {$[\mathrm{gl}+\mathrm{pl}]$} \\
\hline $1146 \pm 2$ & 1 & 96 & $\mathrm{gl}+\mathrm{pl}$ \\
\hline $1115 \pm 3$ & 1 & 95 & $\mathrm{gl}+\mathrm{pl}$ \\
\hline $1110 \pm 2$ & 1 & 201 & {$[\mathrm{gl}+\mathrm{pl}]$} \\
\hline $1105 \pm 2$ & 1 & 247 & $\mathrm{gl}+\mathrm{pl}$ \\
\hline $1087 \pm 3$ & 1 & 195 & $\begin{array}{l}\mathrm{gl}+\mathrm{pl}+\mathrm{px} \\
{[\mathrm{gl}+\mathrm{pl}+\mathrm{opx}+\mathrm{cpx}]}\end{array}$ \\
\hline $1058 \pm 2$ & 1 & 240 & $\begin{array}{l}\mathrm{gl}+\mathrm{pl}+\mathrm{opx} \\
{[\mathrm{gl}+\mathrm{pl}+\mathrm{opx}+\mathrm{cpx}]}\end{array}$ \\
\hline $1021 \pm 2$ & $530 \pm 5$ & 92 & $\begin{array}{c}\mathrm{gl}+\mathrm{pl} \\
{[\mathrm{gl}+\mathrm{pl}]}\end{array}$ \\
\hline $1002 \pm 2$ & $505 \pm 5$ & 112 & $\begin{array}{c}\mathrm{gl}+\mathrm{pl} \\
{[\mathrm{gl}+\mathrm{pl}]}\end{array}$ \\
\hline $992 \pm 2$ & $500 \pm 5$ & 116 & $\mathrm{gl}+\mathrm{pl}$ \\
\hline $956 \pm 2$ & $530 \pm 10$ & 240 & $\begin{array}{c}\mathrm{gl}+\mathrm{pl}+\mathrm{opx} \\
{[\mathrm{gl}+\mathrm{pl}+\mathrm{opx}]}\end{array}$ \\
\hline $982 \pm 2$ & $1015 \pm 5$ & 88.5 & $\mathrm{gl}$ \\
\hline $954 \pm 2$ & $1030 \pm 10$ & 205 & $\begin{array}{c}\mathrm{gl}+\mathrm{pl} \\
{[\mathrm{gl}+\mathrm{pl}]}\end{array}$ \\
\hline $948 \pm 2$ & $985 \pm 5$ & 285 & $\begin{array}{c}\mathrm{gl}+\mathrm{pl} \\
{[\mathrm{gl}+\mathrm{pl}]}\end{array}$ \\
\hline $941 \pm 2$ & $1020 \pm 10$ & 168 & $\begin{array}{l}\mathrm{gl}+\mathrm{pl} \\
{[\mathrm{gl}+\mathrm{pl}+\mathrm{opx}]}\end{array}$ \\
\hline $911 \pm 2$ & $1000 \pm 15$ & 282 & $\begin{array}{c}\mathrm{gl}+\mathrm{pl}+\mathrm{opx} \\
{[\mathrm{gl}+\mathrm{pl}+\mathrm{opx}]}\end{array}$ \\
\hline $935 \pm 2$ & $1310 \pm 10$ & 164 & $\begin{array}{c}\mathrm{gl} \\
{[\mathrm{gl}]}\end{array}$ \\
\hline $919 \pm 2$ & $1340 \pm 10$ & 160 & $\begin{array}{l}\mathrm{gl} \\
{[\mathrm{gl}+\mathrm{pl}]}\end{array}$ \\
\hline $909 \pm 2$ & $1390 \pm 20$ & 236 & $\begin{array}{l}\mathrm{gl}+\mathrm{pl}+\mathrm{opx} \\
{[\mathrm{gl}+\mathrm{pl}]}\end{array}$ \\
\hline $898 \pm 2$ & $1360 \pm 10$ & 303 & $\begin{array}{c}\mathrm{gl}+\mathrm{pl}+\mathrm{opx} \\
{[\mathrm{gl}+\mathrm{pl}+\mathrm{opx}]}\end{array}$ \\
\hline
\end{tabular}

Results with [ ] were from queched glass powders and the others were from the raw rock powders. Abbreviations; $p l=$ plagioclase, $g l=$ liquid(quenched glass), opx=orthopyroxene, $c p x=$ clinopyroxene, $p x=$ pyroxene for which it was difficult to determine ortho- or clino-pyroxene because of its small size. 
ture differed about $20^{\circ} \mathrm{C}$ between the two starting materials (Table 3), and the first appearance temperature of orthopyroxene was identical within the temperature interval investigated (1058 to $1087^{\circ} \mathrm{C}$ in Fig. 1). Under the $\mathrm{H}_{2} \mathrm{O}$ saturated conditions, two capsules containing the two types of starting materials were set indepentendly. Out of the 13 runs, only two runs showed different results; one at 1340 bar and $919^{\circ} \mathrm{C}$ for 160 hours and the other at 1390 bar and $909^{\circ} \mathrm{C}$ for 236 hours. In the former run, no new crystalline phase was identified from the rock powder, but plagioclase started to grow from the glass sample. In the latter, both plagioclase and orthopyroxene were identified as grown phases from the rock powder sample, while only plagioclase crystallized from the glass sample. However, in the run at 1360 bar and $898^{\circ} \mathrm{C}$ for 303 hours, plagioclase and orthopyroxene were identified from both starting matereials. The temperature difference between the above three runs is only $21^{\circ}$ and the temperature and pressure appear to be very close to the crossing condition of the plagioclase and orthopyroxene liquidi (Fig. 1). Therefore, it is considered that the equilibrium state has been attained in each run. Clinopyroxene was not observed in the run products under $\mathrm{H}_{2} \mathrm{O}$-saturated conditions. The lack of clinopyroxene may be due to more depressed clinopyroxene liquidus than that of orthopyroxene.

As summarized in Fig. 1, plagioclase is still a liquidus phase at $1360 \pm 30 \mathrm{bar}$, and an extraporation will give a crossing point at 1500 to 1600 -bar water pressure and 890 to $900^{\circ} \mathrm{C}$ temperature where plagioclase and orthopyroxene crystallize from the liquid simultaneously. Titanomagnetite was not observed in the run products. This indicates that the magmatic $\mathrm{fo}_{2}$ was significantly higher than that of the $\mathrm{Ni}-\mathrm{NiO}$ buffer. Amphibole was not found in the 1977 pumice and not observed in the run products.

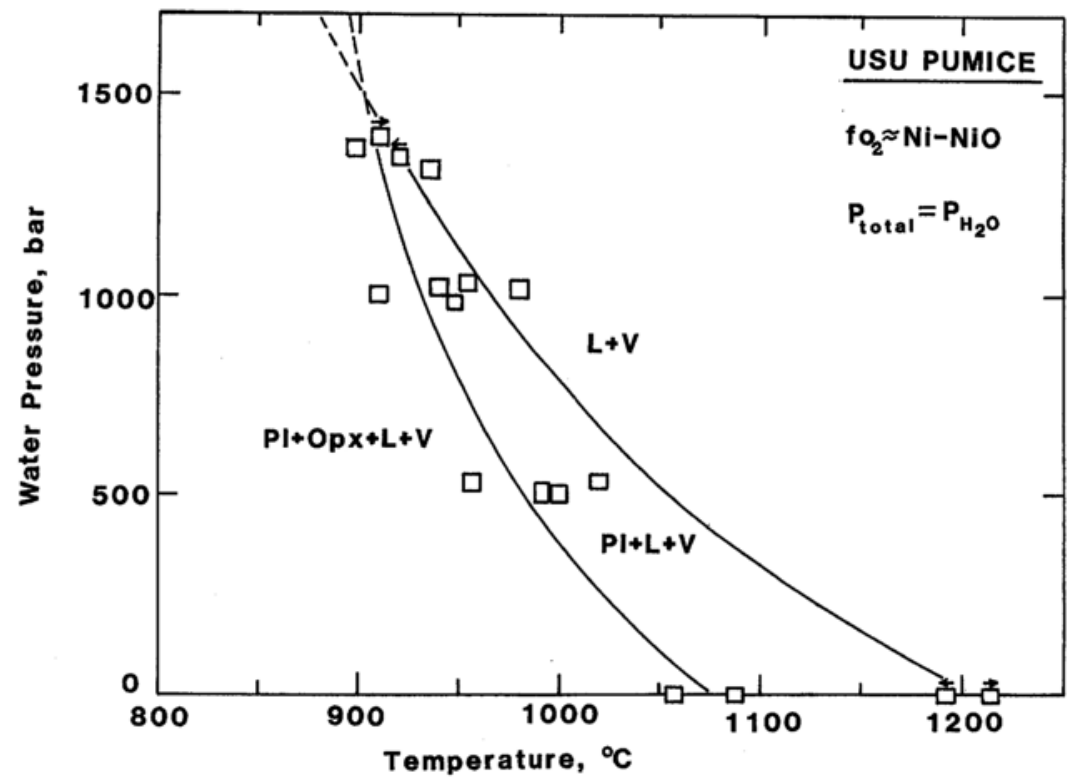

Fig. 1. Temperature-water pressure diagram of phase relations for the Usu pumice (for its composition, see Table 2) under $\mathrm{H}_{2} \mathrm{O}$-saturated conditions and oxygen fugacity $\left(\mathrm{fo}_{2}\right)$ close to the $\mathrm{Ni}-\mathrm{NiO}$ buffer. The arrow indicating the right hand direction denotes the resulis with rock powder starting material, while the arrow indicating the left hand is that with glass starting material (see Table 3 in detail). Squares without arrows indicate the results identical for the two starting materials. Only critical 1-bar results are shown. Abbreviations: $P l=$ plagioclase, $O p x=$ orthopyroxene, $L=$ liquid(quenched glass), and $V=$ vapor. 


\section{Discussion}

\section{Physical conditions of the 1977 Usu eruption}

The crossing condition of plagioclase and orthopyroxene liquidi in the Usu pumice has been estimated to be about 1500 bar water pressure and at a temperature of $900 \pm 10^{\circ} \mathrm{C}$. If a very small amount of the observed phenocrysts is assumed to have been in equilibrium with an $\mathrm{H}_{2} \mathrm{O}$-saturated magma of the Usu pumice composition, then the experimentally determined crossing point corresponds to the physical condition just prior to eruption. This assumption is supported to be reasonable by the fact that the crossing temperature is very close to the estimated one $\left(900 \pm 50^{\circ} \mathrm{C}\right)$ of magnetite-magma equilibrium by Oshima (1977), although the crystallization temperature of magnetite is strongly dependent on $\mathrm{fo}_{2}$.

The assumptin of the $\mathrm{H}_{2} \mathrm{O}$-saturation of the magma just prior to eruption may be considered valid for large-scale eruptions which produce well vesiculated pumice (Sekine et al., 1979). The minimum depth where a magma ascends before explosive eruptions is equivalent to the pressure of $\mathrm{H}_{2} \mathrm{O}$-saturation in the absence of overdriven pressure. Our experimental results indicate that the water pressure just prior to eruption was about $1500 \mathrm{bar}$, whereas the gas pressure calculated using the deduced initial velocity of ejecta (Katsui et al., 1978) is about 700 bar in the Big IV event. These pressures correspond to the depths of 5.3 and $2.5 \mathrm{~km}$, respectively. The activity of the forerunning earthquakes started about 30 hours before the eruption and the foci were located at much shallower depths (1 to 2 km) (Yokoyama et al., 1981). This would imply that the 700-bar pressure was the gas pressure of the magma at the time of eruption after the main conduit opened up and that the 1500-bar water pressure was the one in the magma chamber which was located at a deeper level, say some 6 $\mathrm{km}$ deep. The phenocrysts had to have equilibrated with magma in the magma chamber shortly before eruption. The groundmass minerals may grow during this stage. During magma's slow ascent through the conduit, some part of dissolved water was expelled from the magma and the expansion of the gas at shallower depths caused cracking the top and surrounding wallrocks to generate the forerunning earthquakes. The amount of the $\mathrm{H}_{2} \mathrm{O}$ expelled before the explosive eruption of the Big IV event is estimated to be roughly half of the original $\mathrm{H}_{2} \mathrm{O}$ content of the magma based on the pressure difference.

The occurrence of shocks, observed locally in historic time, preceding each eruption, is one of the characteristic features of the volcanic activity of Usu, which may be related to high viscosity of magma (Minakami et al., 1951; Yokoyama et al., 1981). Petrochemically, the increase in vapor pressure before the eruption is also supported by higher anorthite content in the margins of the phenocrystic plagioclase than that in the core (Katsui et al., 1978). Therefore, it is likely that just prior to eruption the upper part of the Usu magma chamber was at a water pressure of $1500 \pm 100 \mathrm{bar}$ and the temperature was $900 \pm 10^{\circ} \mathrm{C}$.

\section{Comparison of $\mathrm{H}_{2} \mathrm{O}$-saturated phase relations in felsic rocks}

The Usu pumice used in the present study has a similar chemical composition to those of the groundmasses of the Asama pumice in 1783 and the Sakurajima pumice in 1914, except for the $\mathrm{Al}_{2} \mathrm{O}_{3}, \mathrm{CaO}, \mathrm{Na}_{2} \mathrm{O}$, and $\mathrm{K}_{2} \mathrm{O}$ contents. The crossing point of plagioclase and orthopyroxene liquidi of the Usu pumice in the $\mathrm{P}_{\mathrm{H}_{2} \mathrm{O}}$-T projection (Fig. 1) is significantly higher in $\mathrm{P}_{\mathrm{H}_{2} \mathrm{O}}$ and lower in $\mathrm{T}$ than those of the latter two pumices (Table 4). This should be primarily attributed to a difference in the chemical compositions. The Usu pumice has higher $\mathrm{Al}_{2} \mathrm{O}_{3}, \mathrm{CaO}$ and $\mathrm{Na}_{2} \mathrm{O}$ and lower $\mathrm{K}_{2} \mathrm{O}$ relative to the Asama and Sakurajima pumices, corresponding to higher albite and anorthite contents and lower orthoclase in the norm. As a result, plagioclase can survive up to higher water pressure and lower temperature for a crossing condition.

In more felsic pumices (Ito, Osumi, and Kamewarizaka) of which liquidus phase relations were determined experimentally by 
Table 4. Summary of chemical compositions and crossing conditions of plagioclase and pyroxene(s) or plagioclase and quartz liquidi under $\mathrm{H}_{2} \mathrm{O}$-saturated pressures

\begin{tabular}{|c|c|c|c|c|c|c|c|c|c|}
\hline \multirow{3}{*}{ No. } & \multirow{3}{*}{ symbol } & \multicolumn{2}{|c|}{ crossing condition } & \multicolumn{6}{|c|}{ composition (\%) } \\
\hline & & & P(bar) & $\mathrm{SiO}_{2}$ & An & & DI & Dx & Pl \\
\hline & & $\mathrm{T}\left({ }^{\circ} \mathrm{C}\right)$ & $\mathrm{H}_{2} \mathrm{O}$ & wt $\%$ & $\overline{\mathrm{An}+\mathrm{Ab}}$ & QZ & PI & $P X$ & $\overline{\mathrm{Pl}+\mathrm{Px}}$ \\
\hline
\end{tabular}

Akita-komagatake. 1970

1. Whole rock, ejecta of Nov. 11, 1970

2. Groungmass of R-2

3. Artificial mixture corresponding to the glass of GRM-4

Asama. 1783

4. Glass(=groundmass) of early stage pumice

5. Groundmass of late stage lava flow Sakurajima. 1914-1915

6. Glass(=groundmass) of earlist stge pumice

7. Groundmass of early stage lava flow

8. Groundmass of late stage lava flow Usu. 1977

9. Big IV pumice of Aug. 14, 1977 Ito

10. Glass(=groundmass) of matrix

11. Glass(=groundmass) of pumice Osumi

12. Glass(=groundmass) of pumice Kamewarizaka

13. Glass(=groundmass) of pumice Ikeda

14. Glass(=groundmass) of air-fall pumice $36 \mathrm{G}$

15. Glass(=groundmass) of pyroclastic flow $37 \mathrm{G}$ St. Helens. 1980

16. Pumice of May 18, 1980

Mt. Hood. late Pleistocene

17. Andesite, whole rock

Paricutin. 1943-1952

18. Early lava, whole rock

19. Late lava, whole rock

\section{Klyuchevskaya}

20. Whole rock of lova flow

\section{Model systems}

21. $\mathrm{An}-\mathrm{Ab}-\mathrm{Mg}_{2} \mathrm{SiO}_{4}-\mathrm{SiO}_{2}-\mathrm{Fe}-\mathrm{O}$

22.

23.

24.

25. $\mathrm{Ab}-\mathrm{Di}$

26.

27. An-Di

28.

29.

30. $\mathrm{Ab}-\mathrm{Qz}$

$\begin{array}{llccccccc}\text { R-2 } & 1030(5) & 700(50) & 58.6 & 49 & 17 & 62 & 21 & 75.1 \\ \text { GRM-4 } & 1090(5) & 150(30) & 61.1 & 40 & 23 & 59 & 17 & 77.3 \\ \text { MIX-2 } & 1100(10) & 1 & 66.2 & 17 & 30 & 55 & 15 & 78.1\end{array}$

$\begin{array}{lllllllll}\mathrm{P}_{\mathrm{A}}-\mathrm{G} & 960(5) & 800(50) & 69.1 & 36 & 36 & 58 & 7 & 89.6\end{array}$

$\begin{array}{lllllllll}\text { GRM-I } & 1045(5) & 400(50) & 66.2 & 38 & 27 & 60 & 13 & 82.4\end{array}$

$\begin{array}{lcccccccc}\text { P }_{\mathrm{S}}-\mathrm{G} & 950(5) & 800(50) & 68.5 & 26 & 31 & 61 & 8 & 87.4 \\ \mathrm{I}-\mathrm{GRM} & 1010(10) & 500(50) & 65.4 & 31 & 30 & 58 & 12 & 82.5\end{array}$

$\begin{array}{lllllllll}\text { II-GRM } & 1080(5) & 180(50) & 64.1 & 31 & 25 & 59 & 16 & 78.9\end{array}$

$\begin{array}{lllllllll}\mathrm{P}_{\mathrm{U}} & 900(10) & 1500(100) & 68.6 & 33 & 32 & 63 & 5 & 89.4\end{array}$

$\begin{array}{lllllllll}\text { Mi-G } & 770(20) & 1850(100) & 75.1 & 13 & 54 & 45 & 1 & 98.4\end{array}$

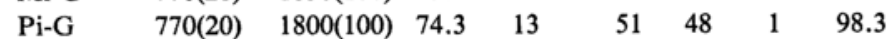

$\begin{array}{lllllllll}\text { Po-G } & 780(20) & 1600(150) & 73.7 & 16 & 51 & 47 & 2 & 96.1\end{array}$

$\begin{array}{lllllllll}\text { Pk-G } & 770(20) & 1950(100) & 74.1 & 14 & 49 & 48 & 3 & 94.8\end{array}$

$\begin{array}{llllllll}730(10) & 2100(150) & 72.1 & 15 & 51 & 47 & 2 & 96.5\end{array}$

$\begin{array}{llllllll}730(10) & 220(100) & 74.0 & 14 & 51 & 48 & 2 & 96.2\end{array}$

$\begin{array}{lllllllll}\mathrm{P}_{\mathrm{H}} & 1075(10) & 300(50) & 62.8 & 36 & 15 & 72 & 13 & 84.4\end{array}$

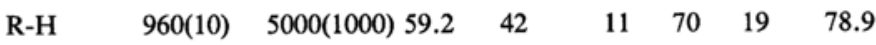

$\begin{array}{lllllllll}\mathrm{W}-47-30 & 1100(10) & 300(50) & 58.4 & 46 & 11 & 69 & 20 & 77.7\end{array}$

$\begin{array}{lllllllll}\text { F-16-52 } & 1080 & 500 & 60.5 & 42 & 12 & 68 & 20 & 76.9\end{array}$

$\begin{array}{lllllllll}\mathrm{R}-\mathrm{K} & 980(10) & 2700(100) & 58.8 & 46 & 10 & 74 & 16 & 82.1\end{array}$

$\begin{array}{rrrrrrrrr}\text { A } & 1145 & 1 & 66.7 & 50 & 32 & 52 & 16 & 77.0 \\ \text { B } & 1135 & 1 & 64.9 & 50 & 35 & 51 & 14 & 73.7 \\ \text { C } & 925 & 1000 & 72.2 & 50 & 44 & 48 & 8 & 86.5 \\ \text { D } & 1005 & 5400 & 69.8 & 50 & 39 & 53 & 8 & 86.2 \\ & 1120 & 1 & 67.4 & 0 & 0 & 90 & 10 & 90.0 \\ & 870 & 2000 & 68.3 & 0 & 0 & 97 & 3 & 97.0 \\ & 1275 & 1 & 50.3 & 100 & 0 & 42 & 58 & 42.0 \\ & 1095 & 5000 & 46.5 & 100 & 0 & 73 & 27 & 73.0 \\ & 1010 & 10000 & 45.6 & 100 & 0 & 78 & 22 & 78.0 \\ & 1160 & 1 & 78.7 & 0 & 32 & 68 & 0 & 100\end{array}$




\begin{tabular}{|c|c|c|c|c|c|c|c|c|c|}
\hline 31. & $" 1$ & 840 & 500 & 81.9 & 0 & 42 & 58 & 0 & 100 \\
\hline 32. & " & 800 & 1000 & 81.6 & 0 & 41 & 59 & 0 & 100 \\
\hline 33. & $" 1$ & 770 & 2000 & 80.3 & 0 & 37 & 63 & 0 & 100 \\
\hline 34. & $" 1$ & 750 & 3000 & 79.7 & 0 & 35 & 65 & 0 & 100 \\
\hline 35. $\mathrm{An}-\mathrm{Qz}$ & & 1370 & 1 & 71.6 & 0 & 50 & 50 & 0 & 100 \\
\hline 36. & $" \prime$ & $1040(10)$ & 1000 & 81.8 & 0 & 68 & 32 & 0 & 100 \\
\hline 37. & $" \prime$ & $922(3)$ & 2000 & 79.0 & 0 & 63 & 37 & 0 & 100 \\
\hline 38. & $" 1$ & $815(5)$ & 5000 & 76.1 & 0 & 58 & 42 & 0 & 100 \\
\hline 39. & $" \prime$ & $575(7)$ & 10000 & 72.6 & 0 & 52 & 48 & 0 & 100 \\
\hline
\end{tabular}

For Nos. 10-15 and 30-39 with the ratios of $\mathrm{Pl} /(\mathrm{Pl}+\mathrm{Px})$ more than 0.94 , the crossings are between plagioclase and quartz. For No. 18, it is between plagioclase and olivine. References are Sekine et al. (1979) for Nos. 1-8, Aramaki (1971) for Nos. 10-13, Ui(1971) for Nos 14 and 15, Rutherford et al. (1985) for No. 16, Eggler and Burnham (1973) for No. 17, Eggler (1972) for Nos. 18 and 19, Makskmov et al. (1978) for No. 20, Eggler (1974) and Eggler and Osborn (1982) for Nos. 21-24, Yoder (1965) for Nos. 25-29, Tuttle and Bowen (1958) for Nos. 30-34, and Stewart (1967) for Nos. 35-39.

Aramaki (1971), the crossings of plagioclase and quartz liquidi, instead of orthopyroxene, have been observed in the $\mathrm{P}_{\mathrm{H}_{2} \mathrm{O}}-\mathrm{T}$ projections. The crossing conditions ranged for water pressures 1600 to 1950 bar and temperatures 770 to $780^{\circ} \mathrm{C}$. Ikeda air-fall pumice determined by Ui (1971) has shown slightly a higher $\mathrm{P}_{\mathrm{H}_{2} \mathrm{O}}(2100 \mathrm{bar})$ and a lower temperature $\left(730^{\circ} \mathrm{C}\right)$ for acrossing condition of plagioclase and quartz liquidi. The chemical compositions are not significantly different each other. Therefore, the difference between the results by Aramaki (1971) and Ui (1971) may be due to experimental uncertainties.

Maaløe and Wyllie (1975) determined isobaric phase relations for a monzogranite from Norway. Their results at 2 kilobar and under $\mathrm{H}_{2} \mathrm{O}$ saturated conditions indicate that plagioclase is still the liquidus phase at $865^{\circ} \mathrm{C}$ and biotite is a subsequent phase at $840^{\circ} \mathrm{C}$. The temperature for the crystallization of quartz was slightly above the solidus temperature $\left(705^{\circ} \mathrm{C}\right)$. The monzogranite composition is slightly richer in $\mathrm{Al}_{2} \mathrm{O}_{3}$, total iron, $\mathrm{CaO}$, and $\mathrm{K}_{2} \mathrm{O}$ and lower in $\mathrm{SiO}_{2}$ than those of the pumices studied by Aramaki (1971) and Ui (1971).

In the system andesite- $\mathrm{H}_{2} \mathrm{O}$ and dacite- $\mathrm{H}_{2} \mathrm{O}$, phase relations for several rocks have been determined by Eggler (1972), Eggler and Burnham (1973), Maksimov et al. (1978), Sekine et al. (1979), Merzbacher and Eggler (1984), and Rutherford et al. (1985 and 1988). The intersections of plagioclase and pyroxene(s) 1 iquidi in the $\mathrm{P}_{\mathrm{H}_{2} \mathrm{O}}-\mathrm{T}$ projections have been experimentally observed at water pressures up to about five kilobars. These results are listed in Table 4, together with those of the synthetic rocks.

Empirical relationships between compositions and physical conditions of magmas before eruptions

The $\mathrm{H}_{2} \mathrm{O}$-saturated liquidus surface for the system $\mathrm{CaMgSi}_{2} \mathrm{O}_{6}(\mathrm{Di})-\mathrm{CaAl}_{2} \mathrm{Si}_{2} \mathrm{O}_{8}(\mathrm{An})-$ $\mathrm{NaAlSi}_{3} \mathrm{O}_{8}(\mathrm{Ab})-\mathrm{SiO}_{2}(\mathrm{Qz})$ at 1 kilobar is illustrated in Fig. 2. Liquidus fields for $\mathrm{Di}$ and the $\mathrm{Ab}-\mathrm{An}$ solid solution $(\mathrm{Pl})$ extend from the ternary surface $\mathrm{Di}-\mathrm{An}-\mathrm{Ab}$ until they meet the liquidus field for Qz. Isotherms on the boundary surface between the liquidus fields for Di and Pl are drawn near the eutectic of the Di-An join at higher temperatures and near the eutectic of the system Di-An-Qz at lower temperatures. With increasing water pressure, the boundary surface between the liquidus fields for $\mathrm{Di}$ and $\mathrm{Pl}$ is expected to shift towards the ternary surface Qz$\mathrm{An}-\mathrm{Ab}$, and each isotherm on it holds on at a relatively similar position. The crossing condition for a fixed composition where plagioclase and diopside precipitate simultaneously can be expressed using three dimensional composition parameters, e.g. An/(An+Ab), $\mathrm{Di} /(\mathrm{Di}+\mathrm{An}+$ $\mathrm{Ab})$, and $\mathrm{Qz} /(\mathrm{Qz}+\mathrm{Di}+\mathrm{An}+\mathrm{Ab})$. Complex natural rocks contain additional components such as $\mathrm{MgSiO}_{3}(\mathrm{En}), \mathrm{CaSiO}_{3}(\mathrm{Wo})$ and $\mathrm{FeSiO}_{3}(\mathrm{Fs}), \mathrm{KAlSi}_{3} \mathrm{O}_{3}$ (Or) and opaque mieals, but the essential features of the phase relations in the $\mathrm{H}_{2} \mathrm{O}$-saturated system $\mathrm{Di}-\mathrm{An}-\mathrm{Ab}-\mathrm{Qz}$ would change little in felsic magmas. For example, the eutectic relations at $1 \mathrm{~atm}$ in the systems 


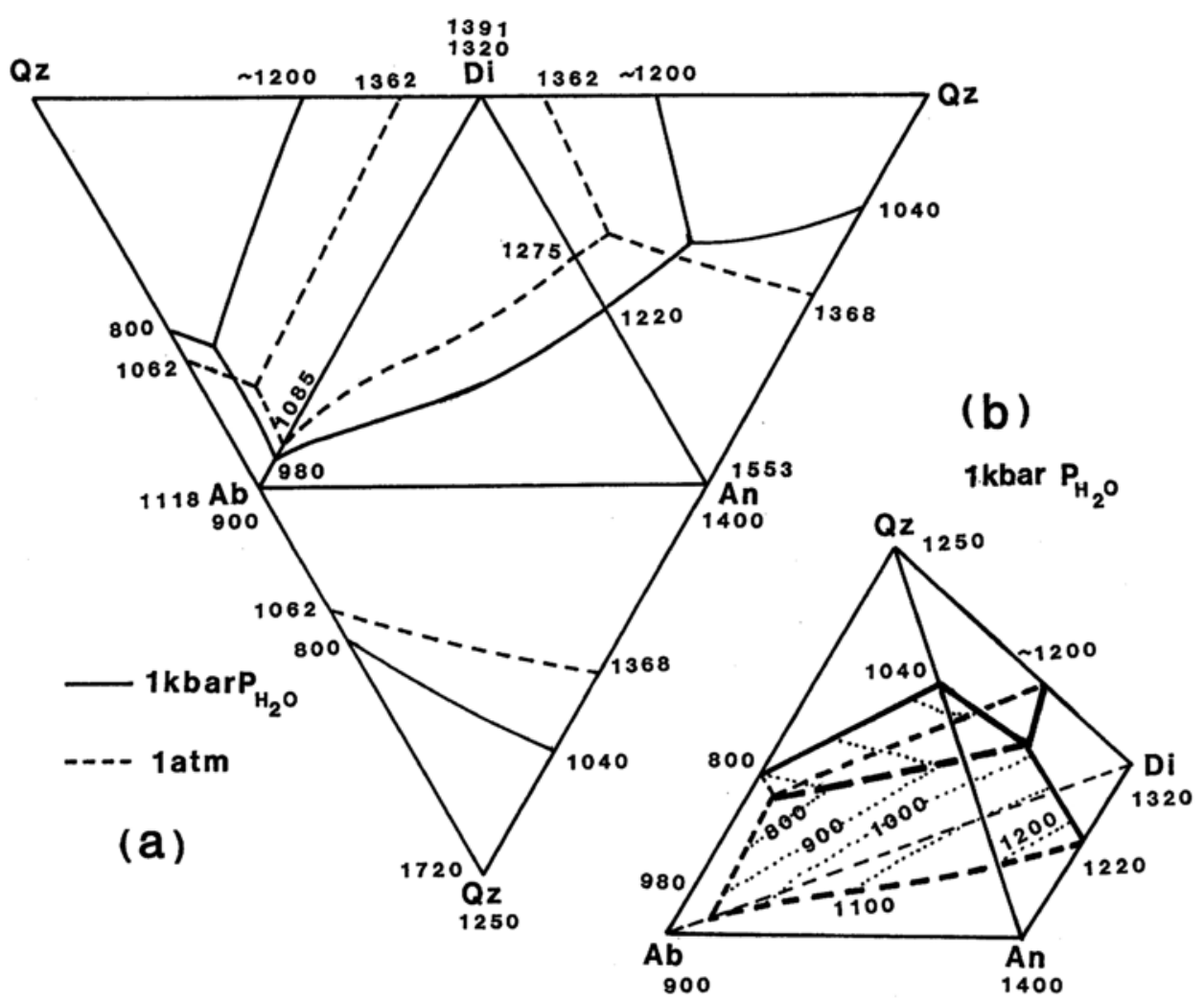

Fig. 2. Schematic diagram showing the liquidus boundaries for diopside, plagioclase and quartz at 1 atm(broken lines in (a)) and under $\mathrm{H}_{2} \mathrm{O}$-saturated conditions at 1 kilobar (solid lines in (a)). Tetrahedron (b) represents the boundaries of the liquidus volumes for diopside, plagioclase and quartz, and the isotherms on the boundary surface (dotted lines in (b)) for plagioclase and diopside and for plagioclase and quartz. The numbers indicate temperatures in ${ }^{\circ} \mathrm{C}$; the greater ones on $\mathrm{Qz}, \mathrm{Ab}, \mathrm{An}$, and $\mathrm{Di}$ at $1 \mathrm{~atm}$, and the smaller ones under $\mathrm{H}_{2} \mathrm{O}$ saturated conditions at 1 kbar. Data are summarized in Table 4.

Qz-Di, Qz-Wo, Qz-En are at $1362^{\circ} \mathrm{C}$ and 17 wt $\% \mathrm{SiO}_{3}$, at $1436^{\circ} \mathrm{C}$ and $21 \mathrm{wt} \% \mathrm{SiO}_{2}$, and at $1543^{\circ} \mathrm{C}$ and $60 \mathrm{wt} \% \mathrm{SiO}_{2}$, in the systems An-Di, An-Wo and An-En at $1275^{\circ} \mathrm{C}$ and $41 \mathrm{wt} \% \mathrm{An}$, at $1307^{\circ} \mathrm{C}$ and $48 \mathrm{wt} \% \mathrm{An}$ and at $1307^{\circ} \mathrm{C}$ and 60 wt $\% \mathrm{An}$, and in the systems Ab-Di, Ab-Wo and $\mathrm{Ab}-\mathrm{En}$ at $1085^{\circ} \mathrm{C}$ and $90 \mathrm{wt} \% \mathrm{Ab}$, at $1125^{\circ} \mathrm{C}$ and $89 \mathrm{wt} \% \mathrm{Ab}$ and at $1097^{\circ} \mathrm{C}$ and $97 \mathrm{wt} \% \mathrm{Ab}$, respectively (Morey, 1964). In these systems, diopside represents the pyroxene component in the systems Qz-pyroxene and Pl-pyroxene.

The crossing conditions of plagioclase and pyroxene(s) liquidi or of plagioclase and quartz liquidi must be a function of the chemical compositions of the starting materials (Sekine, 1986). As shown in Fig. 2, the phase relations in the sim- ple model systems $\mathrm{An}-\mathrm{Di}-\mathrm{H}_{2} \mathrm{O}$ and $\mathrm{Ab}-\mathrm{Di}-\mathrm{H}_{2} \mathrm{O}$ will give a good guide to deduce the crossing conditions in natural rock- $\mathrm{H}_{2} \mathrm{O}$ systems. At pressures below 10 kilobar, the activities of melt components are depressed in the following order, $\mathrm{Ab}=\mathrm{Or}=\mathrm{An}>\mathrm{Qz} \gg \mathrm{Di}=\mathrm{En}=\mathrm{Fs}$ (Burnham, 1979), when another substance $\mathrm{H}_{2} \mathrm{O}$ is added into the systems. Then, the amount of normative Qz may effect more significantly than the variations of normative pyroxene compositions.

All the data for the crossing conditions of plagioclase and pyroxene(s) liquidi, determined experimentally, are given in Fig. 3, and located between the fields fixed by the two systems An$\mathrm{Di}-\mathrm{H}_{2} \mathrm{O}$ and $\mathrm{Ab}-\mathrm{Di}-\mathrm{H}_{2} \mathrm{O}$ in the diagram of water pressure against the normative ratios of 


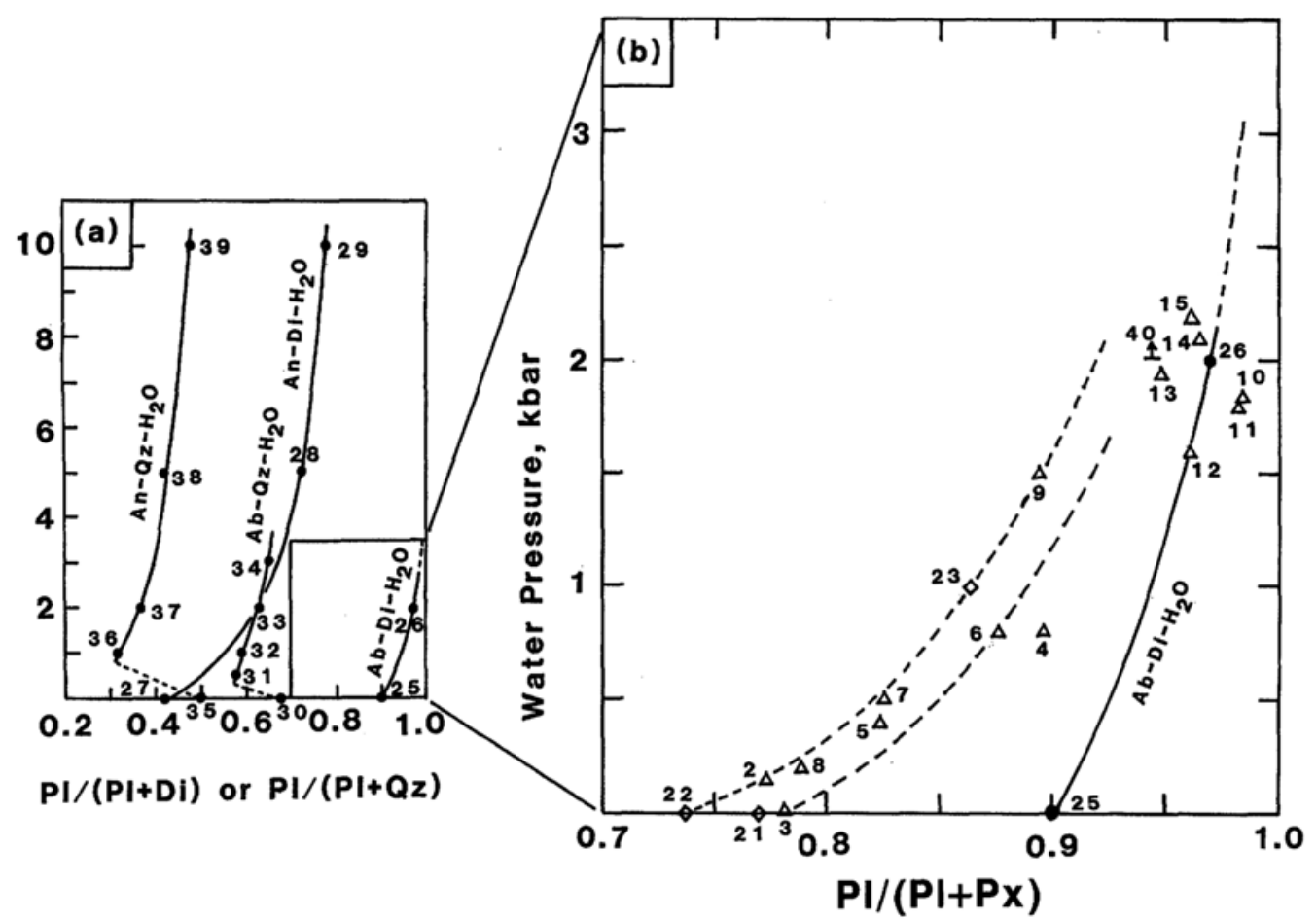

Fig. 3. A relationship between crossing water pressures, determined experimentally under $\mathrm{H}_{2} \mathrm{O}$-saturated conditions, and normative ratios of plagioclase (Pl) to the sum of Pl and pyroxene (Px). A part of $(a)$ is enlarged in (b). Closed circles, connected by solid curves, indicate crossing water pressures for the simple model systems, diamonds for the synthetic rock samples, and triangles for natural groundmass samples. For rocks with the normative $\mathrm{Pl} /(\mathrm{Pl}+\mathrm{Px})$ ratios of 0.94 to 0.99 the crossing occurs between plagioclase and quartz (Aramaki, 1971; $U i, 1971)$. For those with the ratios of 0.74 to 0.90 , the crossings occur between plagioclase and pyroxene(s) with a general trend shown by the two broken curves in (b). All the data except No. 40 are summarized in Table 4. No. 40 refers to the data by Maaløe and Wyllie (1975) that the crossing water prressure is greater than that indicated at 2 kbar.

$\mathrm{Pl} /(\mathrm{Pl}+\mathrm{Px})$, where $\mathrm{Pl}=\mathrm{Ab}+\mathrm{An}$ and $\mathrm{Px}=$ Wo + En + Fs. In this diagram, a relationship between water pressure and normative ratio of $\mathrm{Pl} /(\mathrm{Pl}+\mathrm{Px})$ would be fixed thermodynamically by the ratio of anorthite to albite in the melt if only the three constituents $\mathrm{An}, \mathrm{Ab}$ and $\mathrm{Di}$ affect the crossing condition. As the first approximation, chemical compositions are projected onto the system Pl-Px-Qz. Table 4 lists compositional parameters such as $\mathrm{SiO}_{2}$ in wt\%, normative ratios of $\mathrm{An} /(\mathrm{An}+\mathrm{Ab})$ and $\mathrm{Pl} /(\mathrm{Pl}+\mathrm{Px})$ and crossing temperatures and water pressures. The whole rock compositions of andesites, R-2, W47-30, F-16-52, R-H, K80-25 and R-K are chemically distinct from the more felsic groundmass separated from them, and the crossing water pressures for the whole rocks, even with the same normative ratio of $\mathrm{Pl} /(\mathrm{Pl}+\mathrm{Px})$, are located at higher $\mathrm{P}_{\mathrm{H}_{2} \mathrm{O}}$ than that for the corresponding groundmass (Fig. 3). To estimate the magmatic water pressures we need to know the amount of phenocrysts and a direct relationship is not expected between the compositional parameters of whole rocks and the crossing conditions of plagioclase and pyroxene liquidi. Therefore we will not consider the results for the whole rock data. For the rhyolitic compositions, the crossing water pressures range from 1600 to 2200 bar. The water pressure may increase gradually with increasing normative anorthite and quartz contents according to the simple model systems as shown in Fig. 2 . 
For the dacitic compositions, the crossing water pressures, except for the point $P_{A^{-}}-G$, fall in a narrow zone. As shown in Table 4, $\mathrm{P}_{\mathrm{A}}$-G has the highest ratio of $\mathrm{Qz} /(\mathrm{Qz}+\mathrm{Pl}+\mathrm{Px})$ in the natural dacitic rocks investigated. In the case of $\mathrm{P}_{\mathrm{H}}$, the composition including $40 \%$ phenocryst assemblages does not represent the true liquid composition in the magma just prior to eruption. Therefore, if the ratio of $\mathrm{Qz} /(\mathrm{Qz}+\mathrm{Pl}+\mathrm{Px})$ is over about 0.20 , then there seems to be a close relationship between the compositional parameter of normative ratio $\mathrm{Pl} /(\mathrm{Pl}+\mathrm{Px})$ and the crossing water pressure for dacites, as shown in Fig. 3b. Minor variations may be due to the difference in the normative pyroxene composition. Using this empirical relationship, it is possible to estimate the water pressure and water content in dacitic magmas just prior to eruptions and to predict quantitatively a possible risk of eruption for each volcano constrained by chemical composition. Note that the water pressure deduced from the empirical relationship is a maximum in general.

For the rhyolitic compositions with the normative ratios higher than 0.94 , the crossing water pressures range between 1600 and 2200 bar (average $1900 \pm 300$ bar), where plagioclase and quartz precipitate simultaneously. The water pressure value is comparable with the extraporated one, using the empirical relationship for dacitic compositions (Fig. 3b), to the normative ratio of about 0.93 . There seems to be a maximum crossing water pressure where plagioclase, ortrhopyroxene and quartz coprecipitate from a magma with the normative ratio of about $0.9 \pm 0.01$. In this context, Maaløe

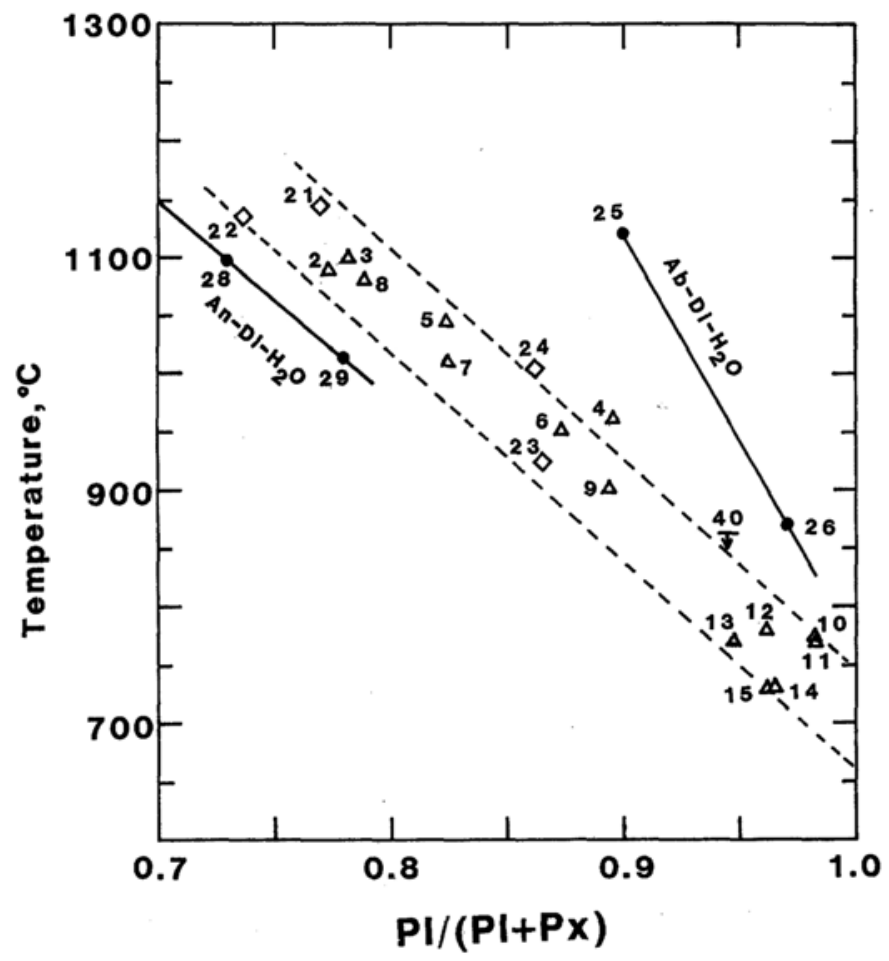

Fig. 4. Relationship between crossing temperatures, determined experimentally under $\mathrm{H}_{2} \mathrm{O}$-saturated conditions, and normative ratios of plagioclase to the sum of plagioclase and pyroxene. For abbreviations, see Fig. 3. All the data except for No. 40 are summarized in Table 4. Note that there is a general trend shown by the two broken curves. No. 40 refers to the results by Maaløe and Wyllie (1975) that the crossing temperature between plagioclase and quartz liquidi is lower than that indicated by the arrow under $\mathrm{H}_{2} \mathrm{O}$-saturated conditions at 2 kbar. 
and Wyllie (1975)'s results on monzogranite with the normative ratio of 0.94 are very interesting that the temperature difference of crystallization between plagioclase and quartz is quite large (about $150^{\circ} \mathrm{C}$ ) under $\mathrm{H}_{2} \mathrm{O}$-sarurated conditions at 2 kilobar. The glass compositions in the pumice and phenocrystic plagioclase inclusion in the Mount St. Helens' magma erupted on May 18,1980 has a normative ratio of 0.91 to 0.92 in terms of $\mathrm{Pl} /(\mathrm{Pl}+\mathrm{Px})$ (Rutherford et al. 1985). The magmatic gas pressure has been estimated $2200 \pm 300$ bar, although the magma is considered to be undersaturated with water (Rutherford et al., 1985). The estimated gas pressure falls within the extraporation using the empirical relationship for the dacitic compositions and almost within the range of the crossing water pressure for rhyolitic compositions if it is assumed to be $\mathrm{H}_{2} \mathrm{O}$-saturated.

Figure 4 illustrates the crossing temperatures, determined experimentally, against the compositional parameter of $\mathrm{Pl} /(\mathrm{Pl}+\mathrm{Px})$. All the data points fall in a narrow band betweeen the two model systems $\mathrm{Ab}-\mathrm{Di}-\mathrm{H}_{2} \mathrm{O}$ and $\mathrm{An}-\mathrm{Di}-\mathrm{H}_{2} \mathrm{O}$. Again, the point $P_{A}-G$ is plotted on slightly higher temperature side relative to the general trend. The generalized trend can be expressed by the equation:

$$
T( \pm 40)^{\circ} \mathrm{C}=2470-1770 X,
$$

where $X$ is the normative ratio $\mathrm{Pl} /(\mathrm{Pl}+\mathrm{Px})$. It should be noted that the temperature calculated through equation (1) is a minimum one for a magma. Let's consider one example. The temperature for the Mt. St. Helens' magma erupted on May 18, 1980 has been estimated to be at $960 \pm 20^{\circ} \mathrm{C}$ (Rutherford et al., 1985) and 900$925^{\circ} \mathrm{C}$ (Merzbacher and Eggler, 1984) using the experimental phase relations and $868^{\circ}$ to $1000^{\circ} \mathrm{C}$ using the ilmenite-magmetite thermometer (Scheidegger et al., 1982; Melson and Hopson, 1981; Fukuyama et al., 1981; Melson, 1983). The calculation using equation (1) indicates a temperature of $860 \pm 40^{\circ} \mathrm{C}$, which is considered to be the minimum magmatic temperature for the eruption. There are reasonable agreements of the above estimated temperatures.
It should be emphasized that the empirical relations shown in Figs. 3 and 4 are very useful for the estimation of the maximum water pressure and the minimum temperature of a magma. Important, necessary precaution is to use a true liquid composition at the time of eruption instead of the bulk composition of a porphyritic magma. And if the true liquid has an unusual feature such as higher quartz content for decite than those studied experimentally, a correction must be needed by further investigations.

Acknowledgments-We are grateful to T. Katsura and $\mathrm{K}$. Hirota for their encouragement during the course of experiments. Reviewer made significant improvements on the early version.

\section{REFERENCES}

Aramaki, S. (1971) Hydrothermal determination of temperature and water pressure of magma of Aira caldera, Japan. Amer. Mineral. 56, 1760-1768.

Aramaki, S. and Katsura, T. (1973) Petrology and liquidus temperature of the magma of the 1970 eruption of Akita-komagatake volcano, northeast Japan. J. Jan. Assoc. Mineral. Petrol. Econ. Geol, 68, 101-124.

Burnham, C. W. (1979) The importance of volatile constituents. The Evolution of the Igneous Rocks, ed. by H. S. Yoder, Jr. p. 439-482. Princeton University Press.

Eggler, D. H. (1972) Water-saturated and undersaturated melting relations in a Paricutin andesite and an estimation of water content in the natural magma. Contr. Mineral. Petrol. 34, 261-271.

Eggler, D. H. (1974). Application of a portion of the system $\mathrm{CaAl}_{2} \mathrm{Si}_{2} \mathrm{O}_{8}-\mathrm{NaAlSi}_{3} \mathrm{O}_{8}-\mathrm{SiO}_{2}-\mathrm{MgO}-\mathrm{Fe}-\mathrm{O}_{2}-$ $\mathrm{H}_{2} \mathrm{O}-\mathrm{CO}_{2}$ to genesis of the calc-alkaline suite. Amer. J. Sci. 274, 297-315.

Eggler, D. H. and Burnham, C. W. (1973) Crystallization and fractionation trends in the system andesite- $\mathrm{H}_{2} \mathrm{O}-\mathrm{CO}_{2}$ at pressures to $10 \mathrm{~kb}$. Geol. Soc. Amer. Bull. 84, 2517-2532.

Eggler, D. H. and Osborn, E. F. (1982) Experimental studies of the system, $\mathrm{MgO}-\mathrm{FeO}-\mathrm{Fe}_{2} \mathrm{O}_{3}-\mathrm{NaAlSi}_{3} \mathrm{O}_{8}$ $\mathrm{CaAl}_{2} \mathrm{Si}_{2} \mathrm{O}_{8}-\mathrm{SiO}_{2}-\mathrm{a}$ model for subalkaline magma. Amer. J. Sci. 282, 1012-1041.

Fukuyama, H., S kes, M. L. and Holloway, J. R. (1981) Pre-eruption $\mathrm{H}_{2} \mathrm{O}$ content of 1980 Mount St. Helens dacite. EOS Trans. AGU. 62, 1084.

Gill, J. B. (1981) Orogenic andesite and plate tec- 
tonics. Springer-Verlag, p. 390.

Katsui, Y., Oba, Y., Onuma, K., Suzuki, T., Kondo, Y., Watanabe, T., Niida, K., Uda, T., Hagiwara, S., Nagao, T., Nishioawa, J., Yamamoto, M., Ikeda, Y., Katagawa, H., Tsuchiyama, N., Shirahase, M., Nemoto, S., Yokoyama, S., So a, T., Fujita, T., Inaba, K., Koide, K. (1978) Preliminary report of the 1970 eruption of Usu volcano. J. Fac. Sci. Hokkaido University, ser. IV, $18,385-408$.

Maaløe, S. and Wyllie, P. J. (1975) Water content of a granite magma deduced from the sequence of crystallization determined experimentally with water undersaturated conditions. Contr. Mieral. Petrol. 52, 175-191.

Maksimov, A. P., Kadik, A. A., Korovushkina, E. Ye., and Ivanov, B. V. (1978) Crystallization of an andesite melt with a fixed water content at pressures up to 12 kbar. Geochemistry Int. 15, 20-29.

Melson, W. G. (1983) Monitoring the 1980-1982 eruptions of Mount St. Helens: compositions and abundances of glass. Science 211, 1387-1391.

Melson, W. G. and Hopson, C. A. (1981) Pre-eruption temperatures and oxygen fugacities in the 1980 eruptive sequence. U.S. Geol. Surv. Prof. Pap. 1250, 641-648.

Merzbacher, C. and Eggler, D. H. (1984) A magmatic geohygrometer: application to Mount St. Helens and other dacitic magmas. Geology 12, 587-590.

Minakami, T., Ishikawa, T., and Yagi, K. (1951) The 1944 eruption of volcano Usu in Hokkaido, Japan. Bull., Volcanol. Ser. II, 11, 45-157.

Niida, K., Katsui, Y., Suzuki, T., and Kondo, Y. (1980) The 1977-1978 eruption of Usu volcano. $J$. Fac. Sci. Hokkaido University, Ser. IV, 19, 357394.

Oshima, O. (1977) Preliminary report on the mineralogy of the 1977 eruption of Usu volcano. Bull. Volcon. Soc. Jap. Ser. 2, 22, 281 (abstract in Japanese).

Rutherford, M. J. and Devine, J. D. (1988) The may
18, 1990 eruption of Mount St. Helens 3. stability and chemistry of amphibole in the magma chamber. J. Geophys. Res. 93, 11949-11959.

Rutherford, M. J., Sigurdsson, H., Carey, S., and Davis, A. (1985) The May 18, 1980, eruption of Mt. St. Helens 1. Melt composition and experi mental phase equilibria. J. Geophys. Res. 90, 2929-2947.

Scheidegger, K. F., Federman, A. M., and Tallman, A. M. (1982) Compositional heterogeneityt of tephras from the 1980 eruptions of Mount St. Helens. J. Geophys. Res. 87, 1086-1088.

Sekine, T. (1986) Liquidus temperature of plagioclase and pyroxene in andesitic melts at one atmosphere. Geochem. J. 20, 287-296.

Sekine, T., Katsura, T., and Aramaki, S. (1977) Hydrothermal melting relation of andesite (1). Bull. Volcanol. Soc. Jap. Ser. 2, 22, 235-240 (in Japanese).

Sekine, T., Katsura, T., and Aramaki, S. (1979) Water saturated phase relations of some andesites with application to the estimation of the initial temperature and water pressure at the time of eruption. Geochim Cosmochim. Acta 43, 1367-1376.

Stewart, D. B. (1967) Four-phase curve in the system $\mathrm{CaAl}_{2} \mathrm{Si}_{2} \mathrm{O}_{8}-\mathrm{SiO}_{2}-\mathrm{H}_{2} \mathrm{O}$ between 1 and 10 kilobars. Schweizer. Mineral. Petrol. Mitt. 47, 35-59.

Tuttle, O. F. and Bowen, N. L. (1958) Origin of granite in the light of experimental studies in the system $\mathrm{NaAlSi}_{3} \mathrm{O}_{8}-\mathrm{KAISi}_{3} \mathrm{O}_{8}-\mathrm{SiO}_{2}-\mathrm{H}_{2} \mathrm{O}$. Geol. Soc. Amer. Memoir. 74, p. 153.

Ui, T. (1971) Genesis of magma and structure of magma chamber of several pyroclastic flows in Japan. J. Fac. Sci. University of Tokyo, Ser. II, 18, 53-127.

Yoder, H. S., Jr. (1966) Spilites and serpentinites. Ann. Rep. Director Geophys. Lab. Carnegie, Inst Washington, Year Book, 65, 269-279.

Yokoyama, I., Yamashita, H., Watanabe, H., and Okada, H. (1981) Geophysical characteristics of dacite volcanism - the 1977-1978 eruption of Usu volcano. J. Volcanol. Geothermal. Res. 9, 335-358. 